\title{
歯科医師の就業状況と診療偶発事故
}

\author{
小野廣 \\ 岡山大学医学部医学科 \\ (指導 : 川上憲人教授)
}

\section{Accidents in dental treatment: a questionnaire investigation}

\author{
Hiroshi Ono \\ Okayama University Medical School, Faculty of Medicine, \\ Okayama 700-8558, Japan \\ (Director : Prof. N. Kawakami)
}

\begin{abstract}
The relationship between the operational situation of dental treatment and accidents experienced was investigated through questionnaires sent to members of the Kagawa Dental Association. Responses were received from 261 dentists (53\% response rate), of whom 113 (43\%) had experienced accidents during dental examinations and/or treatment during the past one year. Dentists with a particularly high risk of having accidents were predominantly young males who possessed many medical chairs at their clinic and who daily examined many patients. Those dentists who worked together with two or more colleagues had a lower risk of accidents. These factors should be considered when trying to take preventive measures against accidents during medical examinations and treatment.
\end{abstract}

キーワード：歯科診療（dental treatment），偶発事故（accident），質問紙調査 (questionnaires）

\section{緒言}

歯科医療に㧍ける診療偶発事故は, 頻度は多くなくとも 重大な事故に繋がる可能性があり，予防の重要性が指摘さ れている ${ }^{1)}$ 。厚生労㗢省も，2006年 4 月からの歯科医師臨 床研修必修化に向けた体制整備に関する検討会の中で，歯 科診療時の全身的偶発事故に適切に対応する能力を歯科医 師臨床研修の到達目標に盛り込んだ2 $。$

診療偶発事故の実態については，いくつかの調査結果が 報告されている ${ }^{3-5)}$. 歯科診療時における異物誤嚥は, イン レー, クラウン，コア等の鋳造物が多く，事故は鋳造物や 技工物を口腔内で試しに適合させる試適中に多い事が報告 されている3).

医療者の属性を変えることはできないが，職場環境や設 備あるいは人間関係のあり方には物理的・心理的に改善の 余地がある ${ }^{6)}$. すなわち，どのような就業状況にある歯科 医師に事故のリスクが高いかを検討することにより，診療 偶発事故の予防対策を講じることが可能となる。しかし，

平成18年 7 月 25 日受理

干767-0002 香川県三豊市高瀬町新名1018-15

医療法人社団 泰公会 小野歯科医院

電話：0875-72-3888 FAX：0875-72-1173

E-mail : onoshikaiin@clock.ocn.ne.jp
歯科医師の診療体制，患者数，スタッフの人数等の就業状 況と診療偶発事故との関連について実証的な報告は少な い。そこで，我々は香川県の歯科医師を対象として，歯科 医師の就業状況と診療偶発事故経験の有無の関連を検討し た。

\section{対象と方法}

香川県歯科医師会全会員490名(男431,女59)に対し,2004 年 2 月初旬より 3 週間の期間で無記名単回の質問紙調査を 行った。香川県歯科医師会を通じて調查票を配布し，回答 後密封の上回収した．調査への回答を持って同意を受ける 手続きとし，261名からの回答を得た(回答率53\%)。

質問票では，年齢，性別，歯科医師としての経験年数を 尋ねた。また，専門を一般歯科，小巟歯科，矯正歯科，口 腔外科のなかから複数回答で選択いただいた．勤務する診 療機関の非常勤を含む歯科医師の人数を，「通常,何人で診 療されていますか」といった問いで尋ね，1人， 2 人，そ れ以上，の選択肢から，歯科医師 1 人当たり 1 日平均して 何人くらいの患者を診療しているかを，～20人，25人，30 人， 35 人， 40 人， 45 人， 50 人〜，といった選択肢から回答 してもらった。このほか，診療機関当たりの歯科医師以外 の診療スタッフ（助手・歯科衛生士・技工士など）の人数 と診療台の数，診療以外の事務などを含む週当たり平均労 
働時間を実数で尋ねた。

解析にあたって, 以下のごとく変数のカテゴリ化を行っ た：年齢 $(<=40,41-50,51-60,61<=$ 歳), 診療スタッフ 人数 $(<=3,4-5,6<=$ 人), 診療台数 $(<=2,3$, $4,5<=$ 台 $)$, 週労働時間 (<=40, 41-50, $51<=$ 時間), 歯科医師数 $(1,2,3$ 人以上 $)$, および 1 日患者数 $(25<$ らい，30-35人くらい，40人以上). 歯科医師としての経験 年数は, 年齢との間に強い相関 $(r=.967, n=256)$ を認め たため, 今回の解析には利用しなかった。また, 診療台数 と診療人数の間に相関は存在するものの強いものではなか ったため (Spearman p =0.360), 本稿では両者を取り入れ て解析することとした。

アウトカム変数としては, 先行研究に習って ${ }^{3-5)}$ 代表的な 診療偶発事故 7 種類の, 過去 1 年および歯科医師として診 療に従事してからの経験の有無について尋ねた。7 種類の うちいずれかひとつでも経験のある者を経験ありとした。 歯科医師の属性および就業状況と診療偶発事故と経験の有 無の関係は, 過去 1 年における経験の有無と歯科医師とし ての診療従事期間中の経験の有無との間で大きな傾向の差 を認めなかったため, 本稿では過去 1 年の診療偶発事故の 経験の有無をアウトカムとした.

研究手続きの倫理的妥当性については, 岡山大学大学院 医歯学総合研究科倫理委員会の承認を得た。

\section{解 析}

調査対象者の属性および就業状況と過去 1 年間における 診療偶発事故経験の有無との関連を $\chi^{2}$ 検定によって観察 した. $2 \times 2$ 表においてはYates の補正を行ったうえで解 析を行った。次いで，歯科医師の属性および就業状況で診 療偶発事故の経験の有無を予測するロジスティック回帰モ デルを構築した。モデルでは調査対象者の属性および就業 状況すべてを独立変数として投入し, 各変数を調整した上 で診療偶発事故の経験を有するオッズ比とその95\%信頼区 間を算出した。P值0.05未満もしくは95\%信頼限界が 1 を またがない関係をもって統計学的に有意とした。統計解析 にはSPSSを使用した。

\section{結果}

表 1 に調査対象の属性と就業状況を示す. 回答者の 9 割 が男性で，これは香川県歯科医師会会員中の男性の割合と ほぼ一致していた。診療科は，一般歯科がもっとも多かっ た。対象者の平均年齢は50歳で, 診療経験年数は平均 24.5 年であった。スタッフ人数の平均は 4.4 人で, 平均 3.9 台の 診療台数が保有され，週当たりの勤務時間は平均43時間で あった。通常診療を担当している医師数は，1 人と回答し
たものが多く，次いで 2 人・ 3 人以上となっており， 2 人 までの診療体制をとっている歯科医療機関が全体の $92 \%$ を

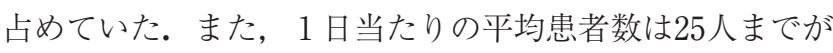
全体の約 6 割を占めた。

表 2 に過去 1 年間における診療偶発事故の経験の有無を

表 1 調査対象の属性と就業状況

\begin{tabular}{|c|c|c|}
\hline & $\mathrm{n}$ & $(\%)$ \\
\hline \multicolumn{3}{|l|}{ 性 別 } \\
\hline 男性 & 233 & 89.3 \\
\hline 女性 & 25 & 9.6 \\
\hline 無回答 & 3 & 1.1 \\
\hline \multicolumn{3}{|l|}{ 専門分野 } \\
\hline 一般歯科 & 190 & 72.8 \\
\hline 矯正歯科 & 2 & 0.8 \\
\hline 小児歯科 & 5 & 1.9 \\
\hline 口腔外科 & 3 & 1.1 \\
\hline 無回答 & 61 & 23.4 \\
\hline \multicolumn{3}{|l|}{ 年＼cjkstart齢 } \\
\hline ～40歳 & 52 & 19.9 \\
\hline $41 ＼mathrm{~ 50 歳 ~}$ & 90 & 34.5 \\
\hline $51 \sim 60$ 歳 & 67 & 25.7 \\
\hline 61歳～ & 47 & 18.0 \\
\hline 無回答 & 5 & 1.9 \\
\hline \multicolumn{3}{|l|}{ スタッフ人数 } \\
\hline 〜 3 人 & 100 & 38.3 \\
\hline $4 \sim 5$ 人 & 89 & 34.1 \\
\hline 6 人〜 & 60 & 23.0 \\
\hline 無回答 & 12 & 4.6 \\
\hline \multicolumn{3}{|l|}{ 診療台数 } \\
\hline$\sim 2$ 台 & 29 & 11.1 \\
\hline 3 台 & 112 & 42.9 \\
\hline 4 台 & 74 & 28.4 \\
\hline 5 台 & 41 & 15.7 \\
\hline 無回答 & 5 & 1.9 \\
\hline \multicolumn{3}{|l|}{ 週労働時間 } \\
\hline ～40時間 & 101 & 38.7 \\
\hline 41～50時間 & 115 & 44.1 \\
\hline 51時間〜 & 39 & 14.9 \\
\hline 無回答 & 6 & 2.3 \\
\hline \multicolumn{3}{|l|}{ 診療体制 } \\
\hline 1 人 & 165 & 63.2 \\
\hline 2 人 & 77 & 29.5 \\
\hline 3 人〜 & 17 & 6.5 \\
\hline 無回答 & 2 & 0.8 \\
\hline \multicolumn{3}{|c|}{1 日当たりの患者数 } \\
\hline ～25人 & 156 & 59.8 \\
\hline $30 \sim 35$ 人 & 59 & 22.6 \\
\hline 40人〜 & 38 & 14.6 \\
\hline 無回答 & 8 & 3.1 \\
\hline
\end{tabular}


内容別に示す．軟部組織損傷については過去 1 年間の平均 経験数がもっとも多く，日常診療において発生頻度の高い 診療偶発事故であった。次いで，異常出血，気管内誤嚥の 頻度が高く，注射針破折・迷入や上顎洞歯根迷入，神経損 傷，気腫は稀な診療偶発事故であった。以上いずれかの診 療偶発事故を，過去 1 年間に経験した歯科医師は 113 人 (43 \%)であった。

表 3 に, 対象者の属性㧍よび就業状況と過去 1 年間にお ける診療偶発事故の経験の有無の関係を示す．診療偶発事 故は，若年の歯科医師に多かった。診療台数が多いほど, また，1日当たりの患者数が多いほど，診療偶発事故が多 かった。また，男性に多い傾向があった．診療体制・週当 たりの労働時間・スタッフの人数は，事故経験の有無と統 計学的に有意な関連はなかった。

ロジスティック回帰解析により各変数を調整すると, 女 性に比べ男性の方が有意に事故のリスクが高いことが認め られた(表 4 )。また，40歳以下の歯科医師は51歳以上の歯 科医師に比べて約 4 倍事故経験のリスクが高かった．診療 体制との関連では，1 人で診療を担当している場合， 3 人 以上で診療を担当している場合と比べて有意に事故のリス クが高かった。診療台数が 5 台以上の施設で診療している 歯科医師は，2 台以下の施設で診療している歯科医師と比 較して 6 倍以上の診療偶発事故のリスクがあった。1 日当

表 2 過去 1 年間における診療偶発事故の経験の有無

\begin{tabular}{|c|c|c|c|}
\hline & & $\mathrm{n}$ & $\%$ \\
\hline \multirow[t]{3}{*}{ 気管内誤嚥 } & あり & 27 & 10.3 \\
\hline & なし & 230 & 88.1 \\
\hline & 無回答 & 4 & 1.5 \\
\hline \multirow[t]{3}{*}{ 軟部組織損傷 } & あり & 70 & 26.8 \\
\hline & なし & 186 & 71.3 \\
\hline & 無回答 & 5 & 1.9 \\
\hline \multirow[t]{3}{*}{ 神経損傷 } & あり & 5 & 1.9 \\
\hline & なし & 253 & 96.9 \\
\hline & 無回答 & 3 & 1.1 \\
\hline \multirow[t]{3}{*}{ 異常出血 } & あり & 46 & 17.6 \\
\hline & なし & 212 & 81.2 \\
\hline & 無回答 & 3 & 1.1 \\
\hline \multirow[t]{3}{*}{ 注射針破折 - 迷入 } & あり & 2 & 0.8 \\
\hline & なし & 256 & 98.1 \\
\hline & 無回答 & 3 & 1.1 \\
\hline \multirow[t]{3}{*}{ 上顎洞歯根迷入 } & あり & 3 & 1.1 \\
\hline & なし & 255 & 97.7 \\
\hline & 無回答 & 3 & 1.1 \\
\hline \multirow[t]{3}{*}{ 気 腫 } & あり & 7 & 2.7 \\
\hline & なし & 251 & 96.2 \\
\hline & 無回答 & 3 & 1.1 \\
\hline
\end{tabular}

たり 30 人以上の患者を診ている歯科医師は，患者数がそれ 以下の歯科医師に比べ $2 \sim 3$ 倍診療偶発事故のリスクが高 かった。スタッフの人数, 週当たりの労働時間と診療偶発 事故経験の間には有意な関連を認めなかった。

診療偶発事故の経験回数や事故内容によって，リスクの 特徵が異なるか否かを見るため, 2 通りのサブ解析を行っ た。

複数回の事故経験者 34 人 (13\%)であった。複数回の事故 を経験したリスクを検討したところ，上記とおおむね同様 の傾向を認めたが，統計学的有意に届いた就業状況は認め られなかった。

さらに事故頻度が相対的に多かった軟部組織損傷と異常 出血の経験の有無をアウトカムとしてロジスティック回帰 モデルを構築した。軟部組織損傷に関しては，年齢が高い ほど事故経験が少なかった（50歳代歯科医師の40歳以下に 対する診療偶発事故経験のオッズ比 $0.20,95 \%$ 信頼区間 0.07-0.53；61歳以上の歯科医師の40歳以下に対する診療 偶発事故経験のオッズ比0.13，95\%信頼区間0.04-0.45).

また診療台数が 5 台以上で 2 台以下の施設に対して有意 に高い診療偶発事故発生のリスクが見られた（オッズ比 7.97,95\%信頼区間1.43-44.36)。このほかの属性㧍よび診 療状況と軟部組織損傷の経験との関倸は, いずれかひとつ の事故経験の有無（表 4 ）と同様の傾向を認めたが有意で はなかった．異常出血をアウトカムとしても同様の傾向を 示したが，統計的有意に届いたリスクを有する歯科医師属 性と就業状況はなかった。

\section{考察}

香川県の歯科医師会会員を対象に質問紙調查を行い，就 業状況と診療偶発事故の関連を検討した。解析対象の 4 割 が過去 1 年間に診療偶発事故を経験していた。男性歯科医 師，若年歯科医師，診療台数を多く保有する歯科医師， 1 日当たりの診療人数が多い歯科医師に診療偶発事故のリス クが高かった。 3 人以上の歯科医師で診療を行っている歯 科医師のリスクは低かった。

1 日当たりの診療人数や保有診療台数は, 歯科医師の仕 事量を反映していると考えられる．就業環境が至適範囲に あるうちは仕事がしやすいが，限界值を超えると作業者の 不快感や機能低下を招き，注意の持続が困難となり，エラ 一が発生しやすくなることが指摘されている ${ }^{6)}$. 心理学的 な仕事の負荷を含む厳しい就業環境は，就業上の事故と関 連する事も示されている7 . 至適範囲以上の仕事量は診療 中の歯科医師の注意を散漫にさせる可能性があるのかもし れない。また，グループ診療を行っている歯科医師に比べ て 1 人診療体制にある歯科医師は心身の疲弊をきたしやす 
表 3 対象者の属性及び就業状況と過去 1 年間における診療偶発事故の経験の有無

\begin{tabular}{|c|c|c|c|c|c|c|}
\hline & \multicolumn{2}{|c|}{ 事故経験なし } & \multicolumn{2}{|c|}{ 事故経験あり } & \multirow{2}{*}{$\chi^{2}$} & \multirow{2}{*}{$\mathrm{p}$} \\
\hline & $\mathrm{n}$ & $\%$ & $\mathrm{n}$ & $\%$ & & \\
\hline \multicolumn{7}{|l|}{ 性＼cjkstart別 } \\
\hline 男性 & 128 & 54.9 & 105 & 45.1 & $3.27^{\dagger}$ & 0.070 \\
\hline 女性 & 19 & 76.0 & 6 & 24.0 & & \\
\hline \multicolumn{7}{|l|}{ 年＼cjkstart齢 } \\
\hline$\sim 40$ 歳 & 23 & 44.2 & 29 & 55.8 & 10.41 & 0.015 \\
\hline $41 \sim 50$ 歳 & 45 & 50.0 & 45 & 50.0 & & \\
\hline $51 \sim 60$ 歳 & 45 & 67.2 & 22 & 32.8 & & \\
\hline 61歳〜 & 32 & 68.1 & 15 & 31.9 & & \\
\hline \multicolumn{7}{|l|}{ スタッフ人数 } \\
\hline ～3人 & 63 & 63.0 & 37 & 37.0 & 5.45 & 0.066 \\
\hline $4 \sim 5$ 人 & 52 & 57.1 & 39 & 42.9 & & \\
\hline 6 人〜 & 27 & 44.3 & 34 & 55.7 & & \\
\hline \multicolumn{7}{|l|}{ 診療台数 } \\
\hline ～2台 & 20 & 69.0 & 9 & 31.0 & 9.34 & 0.025 \\
\hline 3 台 & 68 & 60.7 & 44 & 39.3 & & \\
\hline 4 台 & 43 & 58.1 & 31 & 41.9 & & \\
\hline 5 台〜 & 15 & 36.6 & 26 & 63.4 & & \\
\hline \multicolumn{7}{|l|}{ 週労働時間 } \\
\hline ～40時間 & 61 & 60.4 & 40 & 39.6 & 1.05 & 0.592 \\
\hline $41 \sim 50$ 時間 & 62 & 53.9 & 53 & 46.1 & & \\
\hline 51時間〜 & 21 & 53.8 & 18 & 46.2 & & \\
\hline \multicolumn{7}{|l|}{ 診療体制 } \\
\hline 1 人 & 92 & 55.8 & 73 & 44.2 & 0.51 & 0.775 \\
\hline 2 人 & 44 & 57.1 & 33 & 42.9 & & \\
\hline 3 人〜 & 11 & 64.7 & 6 & 35.3 & & \\
\hline \multicolumn{7}{|c|}{1 日当たりの患者数 } \\
\hline 〜25人 & 105 & 67.3 & 51 & 32.7 & 18.44 & 0.000 \\
\hline $30 \sim 35$ 人 & 22 & 37.3 & 37 & 62.7 & & \\
\hline 40 人〜 & 17 & 44.7 & 21 & 55.3 & & \\
\hline
\end{tabular}

†Yates 補正付

いこと ${ }^{8)}$, 翻って心身疲弊は医療事故の原因となりうるこ とが示唆されている9). 今回の検討で観察されたグループ 診療をしている歯科医師で診療偶発事故のリスクが低いと いう所見は，仕事上の支援の存在が事故の発生に抑制的に 機能していることを示唆するものと思われる．とくに歯科 医師 3 人以上の診療でリスク低下が認められたことは，休 業時のバックアップを含めてより余裕のある体制で事故の リスクが低下することを示唆するものかもしれない. 以上, 歯科医師の仕事量と支援の存在が，診療偶発事故と関連し ている可能性が司見えた。

一方，週当たりの労働時間，スタッフの人数と診療偶発 事故経験の間には，有意な関係が認められなかった。診療 偶発事故は，労働時間の長さよりも，短時間でも多くの人 数を診察しなければいけないといった労働時間の密度との
関係がより強いのかもしれない。スタッフに関しても，人 数の多さより，スタッフ 1 人 1 人のキャリアやスキルの方 が, 診療偶発事故を規定しうる重要な要素なのかもしれな い. 習熟した診療補助は診療に伴う過度な負担を軽減し， 事故のリスクが低減に寄与する可能性がある.

若い歯科医師や男性歯科医師に診療偶発事故が多いこと については，同様の所見が過去の研究でも同様の結果が報 告されている ${ }^{4)}$. 歯科医師以外でも若年者や男性に就業上 の事故が多いことが示されている ${ }^{7,10}$. 若年歯科医師におけ る事故多発は，歯科医師としての経験の浅さが関与してい る可能性がある. 男性歯科医師は女性歯科医師に比べ 4 倍 のオッズ比をもって事故経験が多かった。この関係は，年 齢, 施設あたりのスタッフ人数・保有診療台数, 労働時間, 診療体制, 平均診療患者数によっては説明できなかった。 
表 4 対象者の属性及び就業状況と診療偶発事故の経験の有無 の関係（ロジスティック回帰解析結果）

\begin{tabular}{|c|c|c|c|c|}
\hline \multirow{2}{*}{ 性 別 } & \multirow[t]{2}{*}{ オッズ比 } & \multicolumn{2}{|c|}{ 95\%信頼区間 } & \multirow[t]{2}{*}{$\mathrm{p}$} \\
\hline & & & & \\
\hline 男性 & 1.00 & & & \\
\hline 女性 & 0.20 & 0.06 & 0.67 & .010 \\
\hline \multicolumn{5}{|l|}{ 年＼cjkstart齢 } \\
\hline ～40歳 & 1.00 & & & \\
\hline $41 \sim 50$ 歳 & 0.60 & 0.26 & 1.38 & .273 \\
\hline $51 \sim 60$ 歳 & 0.25 & 0.10 & 0.61 & .003 \\
\hline 61歳〜 & 0.30 & 0.11 & 0.79 & .018 \\
\hline \multicolumn{5}{|l|}{ スタッフ人数 } \\
\hline ～3人 & 1.00 & & & \\
\hline $4 \sim 5$ 人 & 0.60 & 0.27 & 1.32 & .566 \\
\hline 6 人～ & 0.81 & 0.26 & 2.51 & .696 \\
\hline \multicolumn{5}{|l|}{ 診療台数 } \\
\hline ～2台 & 1.00 & & & \\
\hline 3 台 & 1.30 & 0.46 & 3.66 & .603 \\
\hline 4 台 & 1.08 & 0.32 & 3.69 & .929 \\
\hline 5 台〜 & 6.37 & 1.38 & 29.44 & .017 \\
\hline \multicolumn{5}{|l|}{ 週労働時間 } \\
\hline ～40時間 & 1.00 & & & \\
\hline $41 \sim 50$ 時間 & 0.88 & 0.46 & 1.69 & .668 \\
\hline 51時間～ & 0.73 & 0.30 & 1.79 & .515 \\
\hline \multicolumn{5}{|l|}{ 診療体制 } \\
\hline 1 人 & 1.00 & & & \\
\hline 2 人 & 1.23 & 0.59 & 2.56 & .566 \\
\hline 3 人～ & 0.21 & 0.05 & 0.92 & .043 \\
\hline \multicolumn{5}{|c|}{1 日当たりの患者数 } \\
\hline$\sim 25$ 人 & 1.00 & & & \\
\hline $30 \sim 35$ 人 & 3.43 & 1.55 & 7.60 & .004 \\
\hline 40 人〜 & 2.79 & 1.06 & 7.37 & .040 \\
\hline
\end{tabular}

注）各変数をモデル内で調整

パーソナリティやストレスに対する認知や対処行動な ど11), 心理学的な性差など12), 今回の検討されなかった心 理行動学的な要素が関与している可能性がある。これまで の診療偶発事故に関する調査では, 誤嚥がもっとも多いと 報告されているが3,4), 今回の調査では軟部組織損傷が一番 多かった。

診療偶発事故の経験回数や事故内容によって, 本解析で 認められたアウトカムと歯科医師の属性抢よび就業状況間 の関係と大きく異なる所見は認められなかった。サブ解析 に扔いて多くの所見で統計学的有意に届かなかったのは， アウトカム数減少に伴う統計学的パワーの不足に起因する ものと考えられる。

今回の調查は, 香川県歯科医師会に所属する歯科医師だ けを対象にしたものであり，所見を一般化するには慎重で
ある必要があるままた，回答率も53\%と低かった。多忙の 歯科医師からの回答が少なく，また事故経験者が回答を避 けた可能性があり，観察された就業状況と診療偶発事故経 験の関連の強さは過小評価されている可能性がある.また, 横断研究のため因果関係の確定は出来ないが, 診療偶発事 故が多い歯科医師ほど診療人数が多くなるといった逆の関 係は考えにくい.

\section{結論}

歯科医師の属性以外の要因として，1 日当たりの患者数 の多さ，保有診療台数の多さ，1 人診療体制といった就業 状況が診療偶発事故の経験の有無と関連していることが明 らかとなった。これらは歯科医師の診療偶発事故予防対策 を講じる際考慮されてよい要因と思われた。

\section{謝辞}

稿を終えるにあたり，調査に協力いただいた香川県歯科医師会会員 の皆様に謝意を表します。また，ご指導ならびにご校閲を賜った岡山 大学青山英康名誉教授, および岡山大学大学院医歯薬学総合研究科衛 生学・予防医学講座の川上憲人教授に深甚なる感謝の意を表します。

\section{文献}

1) Zeltser R, Cohen C and Casap N : The implications of a broken needle in the pterygomandibular space: clinical guidelines for prevention and retrieval. Pediatr Dent (2002) 24(2), 153-156.

2 ）歯科医師臨床研修必修化に向けた体制整備に関する検討会：「菌 科医師臨床研修に向けた体制整備に関する検討会」報告書, 厚生 労㗢省医政局歯科保健課 (2004).

3）笹尾真美, 野口いづみ, 雨宮義弘：歯科治療時の異物事故につい ての検討一歯科医師に対するアンケート調查から一，日歯麻誌 (1997) 25(5), 723-730.

4 ）馬場雅人, 吉田俊彦, 秋月一城, 香城敦麿, 中条英俊, 太田琇 紀, 中野一博, 諸留 裕, 大網利之, 藤井孝人, 鶴岡一彦: 札幌 歯科医師会の救急医療対策について 第VI報 診療偶発事故アン ケート調查結果 3 年間のまとめ(平成10年〜平成12年)，道歯会 誌 (2003) 58, 247-252.

5）福本潤二, 八尾正巳, 加納 聡, 上田浩志, 田中 彰：歯科治療 中に発生した気管支異物の 3 症例。日歯麻誌（1992）20(4)，718 -724 .

6) 正田 亘：ヒューマンエラーの原因と予防：ヒューマンエラー の心理学一医療・交通・原子力事故はなぜ起こるのか, 大山 正, 丸山康則編, 麗澤大学出版会, 千葉 (2001) pp 139-159.

7 ) Swaen GMH, van Amelsvoort LPGM, Bultmann U, Slangen JJM and Kant IJ : Psychosocial work characteristics as risk factors for being injured in an occupational accident. J Occup Environ Med (2004) 46(6), 521-527.

8 ) Croucher R, Osborne D, Marcenes W and Sheiham A : Burnout and issues of the work environment reported by general dental practitioners in the United Kingdom. Community Dental Health (1998) 15(1), 40-43. 
9 ）北岡(東口)和代：精神科勤務の看護者のバーンアウトと医療事 故の因果関係についての検討. 日本看護科学会誌 (2005) 25(3), 31-40.

10) Laflamme L and Blank VL : Age-related accident risk: longitudinal study of Swedish iron ore miners. Am J Ind Med (1996) 30 (4), 479-487.

11) Christie MD and Shultz KS : Gender differences on coping with job stress and organizational outcomes. Work Stress (1998) 12, 351-361.

12) Hirokawa K, Yagi A and Miyata $Y$ : An experimental examination of the effects of sex and masculinity/femininity on psychological, physiological, and behavioral responses during communication situations. Sex roles (2004) 12, 351-361. 